\title{
Evaluation of pituitary gland anatomy and histopathologic findings in clinically normal horses and horses and ponies with pituitary pars intermedia adenoma
}

\author{
Johannes H. van der Kolk, DVM, PhD; Martin Heinrichs, Dr med vet; Johan D. van Amerongen; \\ Rob C. J. Stooker; Lisette Jansen in de Wal; and Ted S. G. A. M. van den Ingh, DVM, PhD
}

\begin{abstract}
Objective-To determine size and weight of the pituitary gland and associations between pituitary gland size and weight and sex and age in horses without clinical signs associated with pituitary pars intermedia adenoma (PPIA) and horses and ponies with PPIA.
\end{abstract}

Animals-Pituitary glands from 100 horses without clinical signs of PPIA and 19 horses and 17 ponies with PPIA.

Procedures-Pituitary glands were weighed, measured, and examined histologically by use of $H \& E$ stain. Masson trichrome and periodic acid-Schiff staining were used, when appropriate. Histologic lesions in the pars intermedia, pars distalis, or both were classified as no significant lesions, single or multiple cysts, focal or multifocal hyperplasia, single or multiple microadenomas, and adenoma. Relative pituitary weight (RPW) was calculated as pituitary weight (grams) divided by body weight (grams).

Results-There was an age-related increase in the presence of pituitary lesions in the pars distalis and pars intermedia in geldings, mares overall, and nonpregnant mares. Mean ( \pm SD) RPW in horses with PPIA was not significantly different from ponies with PPIA (15 $\pm 5.9 \times 10^{-6}$ and $16 \pm 7.2 \times 10^{-6}$, respectively). Maximum pituitary weight in a horse with PPIA was $13.9 \mathrm{~g}\left(\mathrm{RPW}, 2.9 \times 10^{-5}\right)$. Plasma glucose concentration was positively correlated with RPW in ponies with PPIA.

Conclusions and Clinical Relevance-Pituitary lesions may be a factor in horses with insulin resistance and laminitis before development of clinical signs of PPIA. Ovarian steroids may be involved in the pathogenesis of lesions in the pars intermedia. (Am J Vet Res 2004;65:1701-1707)

$\mathbf{P}$ ituitary pars intermedia adenoma (PPIA) was first described in horses in $1932 .{ }^{1}$ Pituitary pars intermedia adenoma is a frequently confirmed diagnosis in aged horses and ponies. Hyperadrenocorticism in hors-

Received January 21, 2004.

Accepted March 18, 2004.

From the Departments of Equine Sciences, Medicine Section (van der Kolk, Jansen in de Wal) and Veterinary Pathobiology (van Amerongen, Stooker, van den Ingh), Faculty of Veterinary Medicine, Utrecht University, PO Box 80153, 3508 TD Utrecht, The Netherlands; and Drug Safety Evaluation, Aventis Pharma Deutschland GmbH, Mainzer Landstrasse 500, 65795 Hattersheim/Main, Germany (Heinrichs).

The authors thank Petra Scherer and Andrea Schwab for technical assistance.

Address correspondence to Dr. van der Kolk. es and ponies almost invariably originates from an adenoma of the pars intermedia of the pituitary gland., ${ }^{2,3}$ Initially, these animals have hirsutism, which is a remarkable clinical sign. Secondary diabetes mellitus and laminitis have been detected in 38\% and 24\% of cases, respectively, with PPIA. ${ }^{4-8}$ Clinically, however, the diagnosis of PPIA is challenging. Many tests have been used successfully, such as the dexamethasone suppression test, adrenocorticotropic hormone (ACTH) stimulation test, glucose tolerance test, and thyrotropin-releasing hormone test. ${ }^{9}$ In addition, radiography by use of a ventrodorsal radiographic view and computed tomography are also useful., 8,10,11,a However, data on size and weight of the pituitary gland in clinically normal horses and ponies are scarce. Furthermore, data on the association of size and weight of the pituitary gland with age and sex of horses and ponies are also rare. ${ }^{12-15, b}$

The purpose of the study reported here was to determine size and weight of the pituitary gland and associations between pituitary gland size and weight and sex and age in horses without clinical signs associated with PPIA and horses and ponies with PPIA. Early lesions of the pituitary gland and associations between relative pituitary weight (RPW) and plasma ACTH, cortisol, glucose, and insulin concentrations in horses and ponies with PPIA were also investigated.

\section{Materials and Methods}

Animals-Pituitary glands obtained at necropsy from 100 Dutch Warmblood horses (69 mares, 26 geldings, and 5 stallions) that had been submitted to Utrecht University for reasons unrelated to pituitary lesions were examined. None of the horses had overt clinical signs of PPIA prior to euthanasia. Horses ranged in age from 2 to 28 years (mean, $11.6 \pm 5.6$ years $)$.

In addition, records of 19 Dutch Warmbloods and 17 ponies with PPIA that had been examined and hospitalized at Utrecht University were reviewed. Of the 19 horses with PPIA, 11 were mares and 8 were geldings. Horses ranged in age from 10 to 32 years (mean $\pm \mathrm{SD}, 21.0 \pm 6.1$ years). Of the 17 ponies with PPIA, 13 were mares, 3 were geldings, and 1 was a stallion. Ponies ranged in age from 12 to 35 years (mean, $21.1 \pm 5.6$ years). A physical examination, $\mathrm{CBC}$, and serum biochemical analyses were performed on all horses. In all horses and ponies, a presumptive diagnosis of PPIA had been made on the basis of clinical appearance (especially hirsutism) or other clinical signs associated with PPIA. To be included in the study, the clinicopathologic diagnosis of a neoplasm of the pars intermedia of the pituitary gland must have been histologically confirmed postmortem in horses and ponies. 
Histologic examinations-Pituitary glands from all horses were weighed, measured, and examined histologically. Pituitary glands were fixed in neutral-buffered $4 \%$ formalin and embedded in paraffin. Before fixation, pituitary glands were weighed and measured in both the transverse (length and width) and the sagittal planes (height) followed by dissection as described previously. ${ }^{16}$ Sections of 5 to $7 \mu \mathrm{m}$ were mounted and stained with $H \& E$ stain. Masson trichrome and periodic acid-Schiff stains were used when appropriate.

Histologic lesions in the pars intermedia, pars distalis, or both were classified as 0 , no significant lesions; 1 , single or multiple cysts ${ }^{5, \mathrm{~b}} ; 2$, focal or multifocal hyperplasia ${ }^{5,6,17, \mathrm{~b}} ; 3$, single or multiple microadenomas $\mathrm{s}^{5, \mathrm{~b}}$; and 4 , adenoma $a^{1,4-8,17}$ (Figure 1). An approximate size of $<0.5 \mathrm{~cm}$ was used to arbitrarily distinguish a microadenoma from an adenoma as previously described. ${ }^{5}$ Relative pituitary weight was calculated as pituitary weight (grams) divided by body weight (grams).

Assays-Plasma ACTH (3 ponies and 4 horses), cortisol ( 6 ponies and 4 horses), insulin ( 4 ponies and 4 horses), and glucose ( 15 ponies and 14 horses) concentrations were determined for this study in horses and ponies with PPIA as previously described. ${ }^{18}$

Statistical analyses-The significance of differences between groups was assessed by the Mann-Whitney test (2tailed). Linear regression was performed by use of computer software. ' Scatter diagrams were plotted, and 95\% confidence intervals (CI) were calculated. The strength of the linear association was assessed by obtaining the correlation coefficient $(r)$ and testing whether it was different from zero by use of the Pearson product moment correlation test (2-tailed). Values of $P<0.05$ were considered significant. Results are reported as mean $\pm \mathrm{SD}$.

\section{Results}

Weight range of pituitary glands in mares was 2.3 to $4.8 \mathrm{~g}$; the 4.8 -g pituitary gland was obtained from a 16-year-old mare 1 week before parturition. Maximal RPW was $8.5 \times 10^{-6}$ in a 16 -year-old mare that was 3 months pregnant (pituitary weight, $4.6 \mathrm{~g}$ ) and the histologic classifications of lesions in the pars intermedia and pars distalis were 3 and 1 , respectively. Weight range of pituitary glands in geldings was 2.1 to $3.8 \mathrm{~g}$; the 3.8-g pituitary gland was from a 14-year-old (histologic classifications of lesions in the pars intermedia and pars distalis were 2 and 1, respectively) and a 19year-old (histologic classifications of lesions in the pars intermedia and pars distalis were 3 and 2, respectively) gelding. Maximal RPW was $7.6 \times 10^{-6}$ in a 27 -year-old gelding (histologic classifications of lesions in the pars intermedia and pars distalis were 2 and 2). Weight range of the pituitary gland in stallions was 2.0 to 3.1 $\mathrm{g}$; the 3.1-g pituitary gland was from a 15-year-old stallion (histologic classifications of lesions in the pars intermedia and pars distalis were 2 and 1 , respectively). Overall, mean RPW in horses $(n=12)$ without clinical signs associated with PPIA measured $6.0 \pm 1.3$ $\times 10^{-6}$ (range, 4.2 to $8.5 \times 10^{-6}$ ).

Mean weight and length of pituitary glands from all mares without clinical signs associated with PPIA were significantly greater than the corresponding values in geldings and stallions (Table 1). In addition, mean weight and length of pituitary glands from nonpregnant mares $(n=26)$ without clinical signs associated with PPIA were also significantly greater than the corresponding values in geldings (26). In lactating mares $(n=22)$ without clinical signs associated with PPIA, mean height and weight of pituitary glands were significantly greater than the corresponding values in geldings. In pregnant mares $(n=13)$ without clinical signs associated with PPIA, mean length, width,
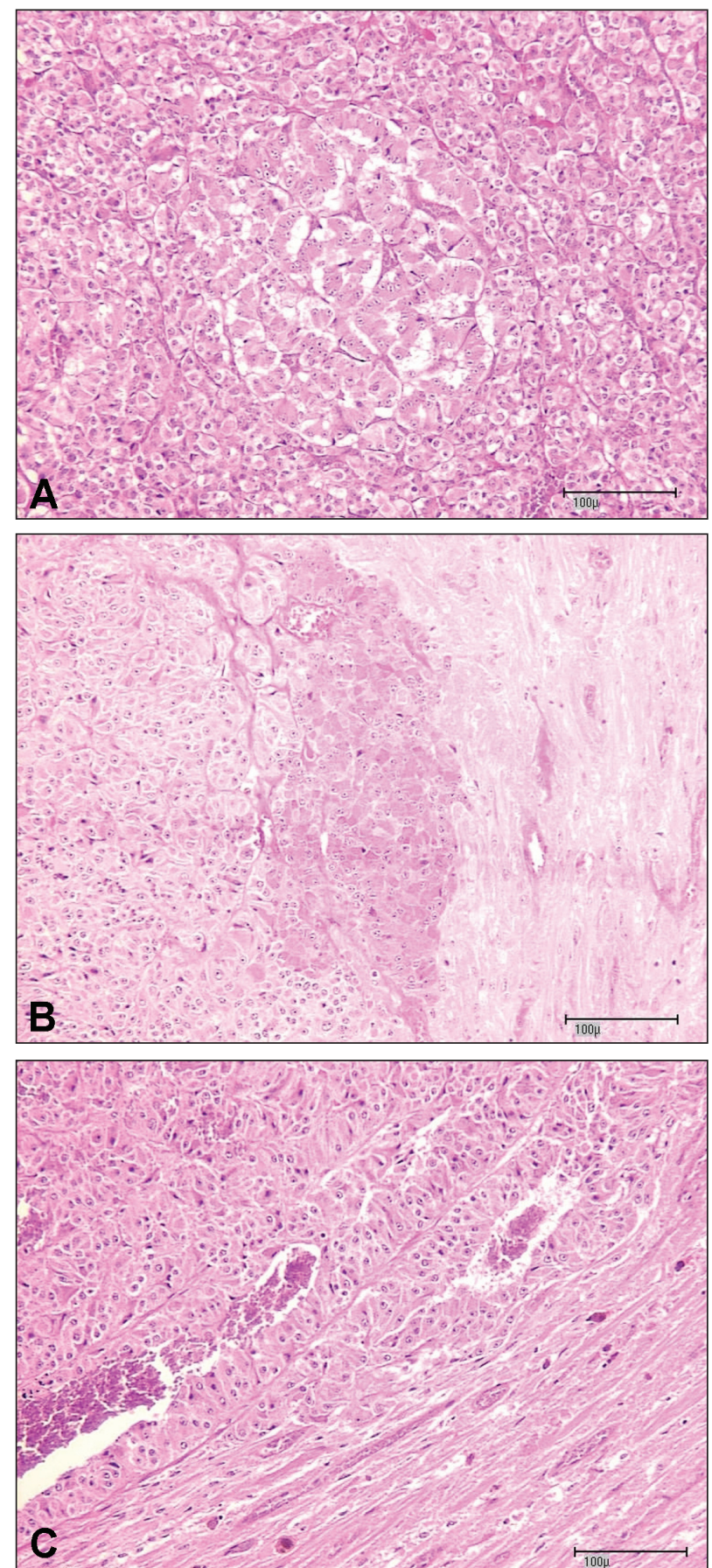

Figure 1-Photomicrographs of sections of representative pituitary gland lesions from horses. A-Focal hyperplasia of the pars distalis in the pituitary gland from a 21-year-old mare. B-Focal hyperplasia of the pars intermedia localized at the junction of the pars nervosa (right) in the pituitary gland from a 27 -year-old gelding. C-Microadenoma of the pars intermedia compressing the adjacent pars nervosa (lower right) in the pituitary gland from a 19-year-old mare. Hemosiderin in the pars nervosa is indicative of previous hemorrhage. In all panels, H\&E stain; bar = $100 \mu \mathrm{m}$. 
Table 1-Association between pituitary gland measurements and sex in horses without clinical signs associated with pituitary pars intermedia adenoma.

\begin{tabular}{|c|c|c|c|c|c|c|}
\hline Sex & $\begin{array}{l}\text { No. of } \\
\text { horses }\end{array}$ & $\begin{array}{c}\text { Age } \\
\text { (range) }\end{array}$ & $\begin{array}{c}\text { Weight } \\
\text { (g) }\end{array}$ & $\begin{array}{l}\text { Length } \\
(\mathbf{m m})\end{array}$ & $\begin{array}{c}\text { Width } \\
\text { (mm) }\end{array}$ & $\begin{array}{l}\text { Height } \\
(\mathrm{mm})\end{array}$ \\
\hline Mares & 69 & $11.6 \pm 5.0(4-24)$ & $3.4 \pm 0.54^{\mathrm{a}}$ & $24 \pm 1.9^{\mathrm{a}}$ & $21 \pm 2.1$ & $12 \pm 2.0^{\mathrm{a}}$ \\
\hline Geldings & 26 & $11.2 \pm 6.4(3-27)$ & $2.8 \pm 0.44^{b}$ & $23 \pm 1.6^{b}$ & $21 \pm 1.8$ & $11 \pm 1.6^{b}$ \\
\hline Stallions & 5 & $12.8 \pm 8.7(2-28)$ & $2.5 \pm 0.36^{b}$ & $21 \pm 1.2^{b, c}$ & $19 \pm 1.0$ & $10 \pm 1.5^{\mathrm{a}, \mathrm{b}}$ \\
\hline
\end{tabular}

Table 2-Association between pituitary gland measurements and reproductive stages in mares without clinical signs associated with pituitary pars intermedia adenoma.

\begin{tabular}{|lcccccc|}
\hline Stage & $\begin{array}{c}\text { No. of } \\
\text { horses }\end{array}$ & Age $^{*}$ (range) & Weight $(\mathbf{g})$ & Length $(\mathbf{m m})$ & Width $(\mathbf{m m})$ & Height $(\mathbf{m m})$ \\
\hline Lactation & 22 & $11 \pm 4.6(4-21)$ & $3.5 \pm 0.54^{\mathrm{a}, \mathrm{c}}$ & $23 \pm 1.7$ & $20 \pm 2.3^{\mathrm{a}}$ & $12 \pm 1.9^{\mathrm{a}, \mathrm{c}}$ \\
Pregnant & 13 & $12 \pm 4.3(6-19)$ & $3.8 \pm 0.53^{\mathrm{b}, \mathrm{c}}$ & $24 \pm 1.8$ & $22 \pm 2.0^{\mathrm{b}}$ & $13 \pm 2.1^{\mathrm{b}, \mathrm{c}}$ \\
Nonpregnant & 26 & $12 \pm 5.4(5-24)$ & $3.2 \pm 0.43^{\mathrm{a}}$ & $24 \pm 2.0$ & $21 \pm 2.0^{\mathrm{b}}$ & $11 \pm 1.8^{\mathrm{a}}$ \\
\hline
\end{tabular}

height, and weight of pituitary glands were significantly greater than the corresponding values in geldings and stallions (5). Only the width of the pituitary gland differed significantly (larger in pregnant mares) between lactating $(\mathrm{n}=22)$ and pregnant (13) mares without clinial signs associated with PPIA (Table 2).

There were significant differences between mean weight and height of pituitary glands in horses $\leq 10$ years $(n=51)$ and $>11$ years old (49) without clinical signs associated with PPIA; horses $>11$ years old had the highest values. There was a significant correlation $(r=0.248 ; P=0.013)$ between pituitary gland weight and age in horses without clinical signs associated with PPIA $(\mathrm{n}=100$; Figure 2$)$. The linear regression equation was pituitary gland weight $($ grams $)=0.02561 X$ age (years) +2.872 (measured $95 \%$ CI, 2.0 to 4.3 ; calculated $95 \% \mathrm{CI}, 2.9$ to $3.5 ; P=0.013)$. A significant correlation $(r=0.414 ; P=0.035)$ was detected between pituitary gland weight and age in geldings $(n=26)$; the linear regression equation was pituitary gland weight (grams) $=0.02846 \times$ age (years) +2.497 (measured $95 \% \mathrm{CI}, 1.9$ to 3.7 ; calculated $95 \% \mathrm{CI}, 2.5$ to $3.2 ; P=$ $0.035)$. A significant correlation $(r=0.244 ; P=0.043)$ was detected between pituitary gland weight and age in mares $(n=69)$; the linear regression equation was pituitary gland weight (grams) $=0.02668 \times$ age (years) + 3.040 (measured 95\% CI, 2.3 to 4.4; calculated $95 \%$ CI, 3.1 to $3.6 ; P=0.043$ ). No significant correlation was detected between pituitary weight and age in both reproductive stages in mares. Results of the corresponding calculations between RPW and age were not significantly different, or the calculations were not performed because of insufficient data.

There was a significant correlation between age and the presence of pituitary lesions in the pars distalis $(r=0.409 ; P=0.000)$ and pars intermedia $(r=0.519$; $P=0.000)$ in horses without clinical signs associated with PPIA. There was a significant correlation between age and the presence of pituitary lesions in the pars dis-

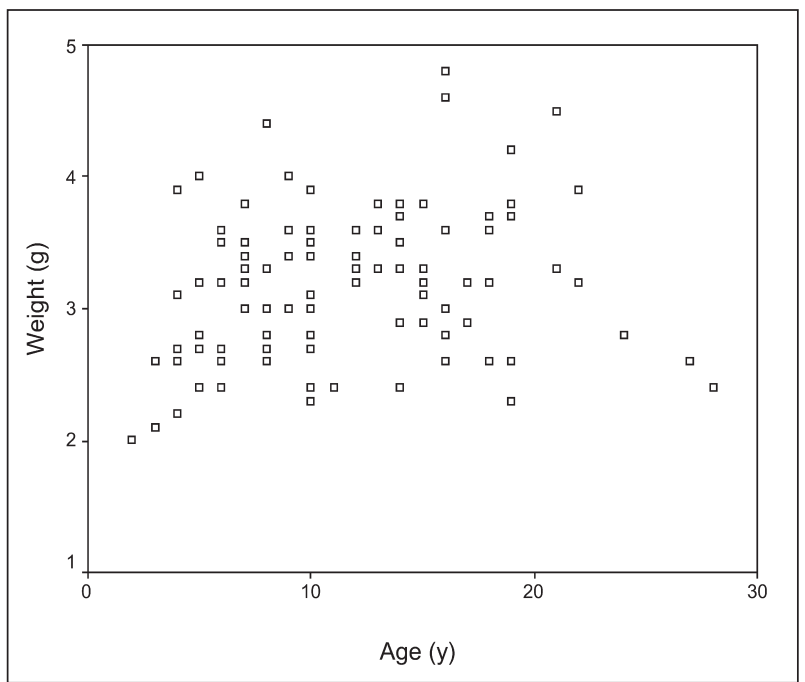

Figure 2-Correlation between pituitary gland weight and age in 100 horses without clinical signs associated with pituitary pars intermedia adenoma $(r=0.248 ; P=0.013)$.

talis $(r=0.554 ; P=0.003)$ and pars intermedia $(r=0.683 ; P=0.000)$ in geldings. There was a significant correlation between age and the presence of pituitary lesions in pars distalis $(r=0.341 ; P=0.004)$ and pars intermedia $(r=0.516 ; P=0.000)$ in mares overall. Interestingly, there was a significant correlation between age and the presence of pituitary lesions in the pars distalis $(r=0.509 ; P=0.008)$ and pars intermedia $(r=0.440 ; P=0.024)$ in nonpregnant mares, whereas there was no significant correlation between age and the presence of pituitary lesions in the pars distalis and pars intermedia in pregnant and lactating mares.

The percentages of lesions in the pars intermedia (histologic classification of lesions 2, 3, and 4) were $55 \%, 84 \%$, and $46 \%$ in lactating, pregnant, and nonpregnant mares $(n=61)$, respectively, without clinical signs associated with PPIA. The pecentage of lesions in 
Table 3-Percentage of histologically classified lesions in the pars distalis and pars intermedia of pituitary glands from horses without clinical signs associated with pituitary pars intermedia adenoma.

\begin{tabular}{|c|c|c|c|c|c|c|c|c|c|c|c|c|}
\hline \multirow[b]{2}{*}{$\underline{\text { Sex }}$} & \multirow[b]{2}{*}{$\begin{array}{c}\text { No. of } \\
\text { horses }\end{array}$} & \multicolumn{5}{|c|}{ Pituitary pars distalis } & \multicolumn{6}{|c|}{ Pituitary pars intermedia } \\
\hline & & 0 & 1 & 2 & 3 & 4 & 0 & 1 & 2 & 3 & 4 & $\begin{array}{c}\text { Sum of } \\
2,3 \text {, and } 4\end{array}$ \\
\hline Mares & 69 & 33 & 57 & 10 & 0 & 0 & 10 & 33 & 36 & 16 & 5 & $57^{\mathrm{a}}$ \\
\hline Geldings & 26 & 23 & 58 & 19 & 0 & 0 & 12 & 62 & 16 & 12 & 0 & $28^{\mathrm{b}}$ \\
\hline Stallions & 5 & 60 & 40 & 0 & 0 & 0 & 20 & 60 & 20 & 0 & 0 & $20^{\mathrm{b}}$ \\
\hline
\end{tabular}

Table 4-Percentage of histologic lesions in the pars distalis and pars intermedia of pituitary glands from horses without clinical signs associated with pituitary pars intermedia adenoma.

\begin{tabular}{|lccccc|}
\hline Sex & No. of horses & No lesions at all & Pars distalis & Pars intermedia & $\begin{array}{c}\text { Pars distalis } \\
\text { and pars } \\
\text { intermedia }\end{array}$ \\
\hline Mare & 69 & 5 & 5 & 29 & $61^{\mathrm{a}}$ \\
Gelding & 26 & 8 & 4 & 15 & $73^{\mathrm{a}, \mathrm{b}}$ \\
Stallion & 5 & 20 & 0 & 40 & $40^{\mathrm{b}}$ \\
\hline \multicolumn{2}{l}{ a,bWithin a column, values with different superscript letters are significantly $(P<0.05)$ different. } \\
\hline
\end{tabular}

the pars distalis (histologic classification of lesions 2 , 3 , and 4 ) were $0 \%, 23 \%$, and $11 \%$ in lactating, pregnant, and nonpregnant mares, respectively, without clinical signs associated with PPIA. There were no significant differences in the number of lesions in either the pars distalis or the pars intermedia among lactating, pregnant, and nonpregnant mares.

Among horses without clinical signs associated with PPIA, a diagnosis of PPIA was made in 3 mares (15 [nonpregnant], 16 [pregnant], and 16 [reproductive stage unknown] years old), which represented $4.4 \%$ of mares and $3 \%$ of all horses in the study. Pituitary glands from mares without clinical signs associated with PPIA contained significantly more lesions in the pars intermedia (histologic classification of lesions 2 to $4 ; 57 \%$ ), compared with geldings (28\%) and stallions (20\%; Table 3). There were no significant differences in the number of lesions in the pars distalis among mares, geldings, and stallions. Pituitary glands from geldings without clinical signs associated with PPIA contained significantly more lesions in the pars intermedia and pars distalis combined (histologic classification of lesions 1 to $4 ; 73 \%)$, compared with mares (61\%) and stallions (40\%; Table 4).

Overall mean values for pituitary gland weight, length, width, and height in 19 horses with PPIA were $7.7 \pm 3.3 \mathrm{~g}, 26.2 \pm 3.1 \mathrm{~mm}, 24.2 \pm 2.6 \mathrm{~mm}$, and $19.2 \pm$ $4.3 \mathrm{~mm}$, respectively. Overall mean values for pituitary gland weight, length, width, and height in 17 ponies with PPIA were $4.3 \pm 1.8 \mathrm{~g}, 23.0 \pm 4.0 \mathrm{~mm}, 20.1 \pm 3.1$ $\mathrm{mm}$, and $15.9 \pm 3.2 \mathrm{~mm}$, respectively.

Maximal pituitary gland weight in horses with PPIA was $13.9 \mathrm{~g}$ and was from a 19-year-old gelding with diabetes mellitus $(33 \times 29 \times 27 \mathrm{~mm}$ for length, width, and height, respectively, and RPW, $\left.2.9 \times 10^{-5}\right)$. Maximal RPW in ponies with PPIA also measured $2.9 \mathrm{X}$ $10^{-5}$ and was detected in a 16-year-old stallion with laminitis (pituitary gland weight, $5.2 \mathrm{~g}$ ). Mean RPW in horses $\left(15 \pm 5.9 \times 10^{-6}\right)$ with PPIA was not significant- ly different from the value in ponies $\left(16 \pm 7.2 \times 10^{-6}\right)$ with PPIA. Furthermore, mean age, plasma glucose concentration, and sex distribution in horses with PPIA were not significantly different from values in ponies with PPIA. There was no significant correlation between age and RPW in ponies $(n=14)$ and horses (14) with PPIA. In warmblood mares with PPIA ( $\mathrm{n}=$ 11), the length, width, height, RPW, and weight of the pituitary gland and age $(20.4 \pm 6.5$ years $)$ were significantly greater than the corresponding values in nonpregnant mares without clinical signs associated with PPIA (26). In warmblood geldings with PPIA $(n=8)$, the length, width, height, RPW, and weight of the pituitary gland and age $(21.8 \pm 5.4$ years $)$ were significantly greater than the corresponding values in geldings without clinical signs associated with PPIA (26). As a comparison, no significant differences in length, width, height, RPW, and weight of the pituitary gland and age were found between warmblood mares and geldings with PPIA. However, values for pituitary gland weight, length, width, and height overlapped in warmblood mares (18\%, 64\%, 73\%, and 18\%, respectively) and geldings $(0 \%, 75 \%, 63 \%$, and $25 \%$, respectively) with PPIA, with the cutoff point (mean +2 SD) calculated from the data from nonpregnant mares and geldings without clinical signs associated with PPIA.

Horses and ponies with PPIA were allocated to various groups on the basis of plasma glucose concentrations and clinical signs. Both pituitary gland weight and RPW in normoglycemic horses (plasma glucose concentration range, 3.9 to $5.6 \mathrm{mmol} / \mathrm{L} ; \mathrm{n}=3$ ) were not significantly smaller than those in hyperglycemic horses (plasma glucose concentration, > $5.6 \mathrm{mmol} / \mathrm{L}$; 11) with PPIA. In contrast, pituitary gland weight, but not RPW, in normoglycemic ponies $(n=6)$ was significantly smaller than that in hyperglycemic ponies (9) with PPIA. In all ponies and horses with PPIA, there were no significant differences in RPW between the groups with laminitis ( $\mathrm{n}=15)$, seizures (3), and other 


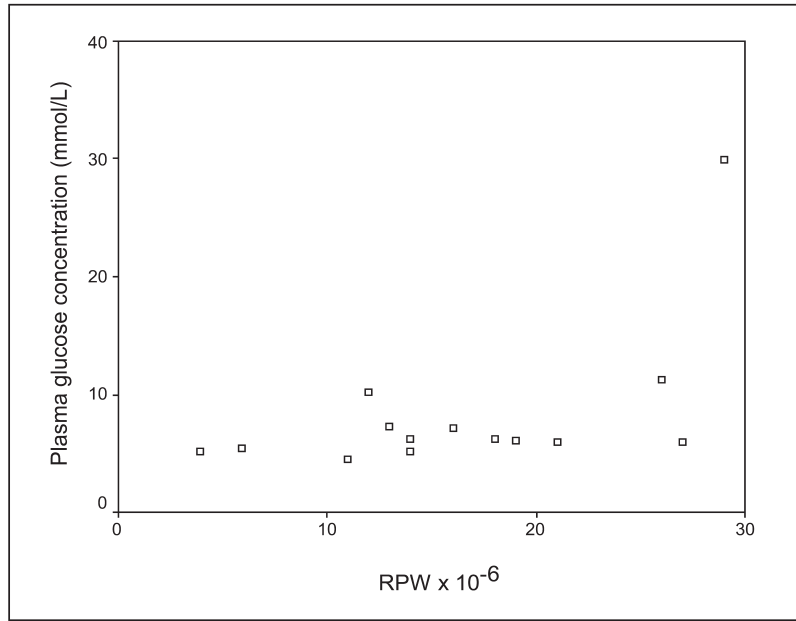

Figure 3-Correlation between plasma glucose concentration and relative pituitary gland weight (RPW) in 14 ponies with pituitary pars intermedia adenoma $(r=0.560 ; P<0.05)$.

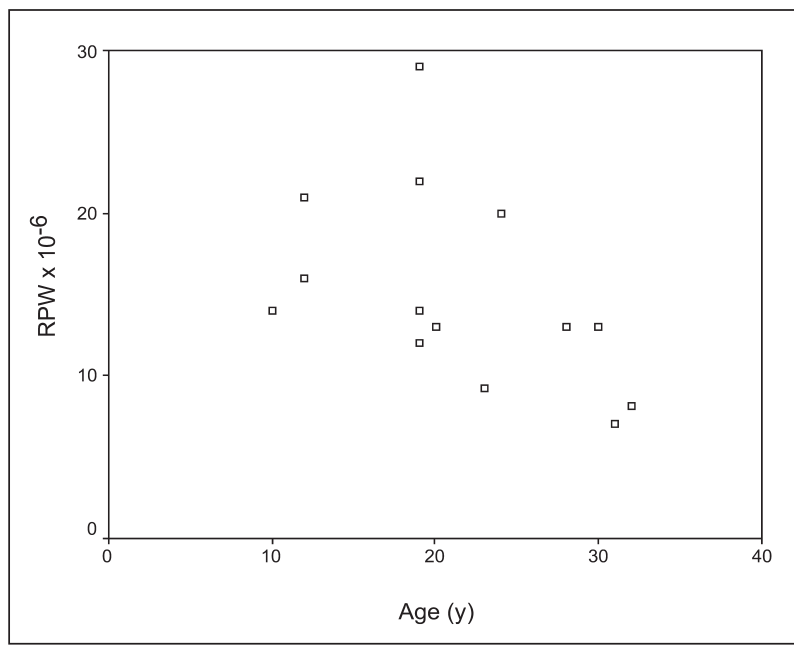

Figure 4-Association between RPW and age in 14 horses with pituitary pars intermedia adenoma $(r=-0.478 ; P=0.084)$.

clinical signs (alveolitis, weight loss [5], infertility [2], delayed wound healing, corneal rupture, sinusitis, aggressive behavior, endometritis, solar ulcer, and inability to stand). In all horses and ponies with PPIA, there was also no significant correlation between RPW and plasma ACTH $(\mathrm{n}=7)$, cortisol (10), or insulin (8) concentrations.

There was a significant correlation $(r=0.560$; $P<0.05)$ between plasma glucose concentration and RPW in ponies with PPIA ( $\mathrm{n}=14$; Figure 3$)$. The linear regression equation was plasma glucose concentration $(\mathrm{mmol} / \mathrm{L})=0.485 \times \mathrm{RPW} \times 10^{6}+0.358$ (measured $95 \% \mathrm{CI},-4.2$ to 20.8 ; calculated $95 \% \mathrm{CI}, 1.4$ to $15.3 \mathrm{mmol} / \mathrm{L} ; P<0.05)$. No significant correlation was detected between plasma glucose concentration and pituitary gland weight in horses. There was no significant correlation $(r=-0.478 ; P=0.084)$ between RPW and age in horses with PPIA ( $\mathrm{n}=14$; Figure 4$)$.

\section{Discussion}

In the study reported here, overall mean pituitary weight in mares without clinical signs associated with
PPIA was $3.2 \pm 0.58 \mathrm{~g}$. This is in agreement with findings of 1 review $^{14}$ indicating that pituitary gland weights in horses ranged from 1.00 to $3.78 \mathrm{~g}$ and results of 1 study $^{\mathrm{b}}$ indicating that the mean pituitary gland weight was $2.78 \mathrm{~g}$. Results of another study ${ }^{15}$ indicate that pituitary gland weights in horses ranged from 1.7 to 3.4 g. For comparison, results of other studies indicate that the pars distalis and pars intermedia weigh 0.9 and $0.15 \mathrm{~g}$, respectively, ${ }^{19}$ and pituitary glands weighed $\leq 3 \mathrm{~g}^{4}$ in clinically normal horses. In addition, results of 1 study ${ }^{20}$ indicate that the mean weights of adenohypophysis (1.08 g), neurohypophysis $(0.30 \mathrm{~g})$, and total pituitary gland $(1.47 \mathrm{~g})$ in control horses 4 to 4.5 months old $(\mathrm{n}=3)$ after 12 months of daily administration of vehicle were not significantly different from those same values in 4- to 4.5-monthold horses (4) after daily administration of equine somatotropin $(20 \mu \mathrm{g} / \mathrm{kg}, \mathrm{IM})$ for 12 months.

In our study, within the group of horses without clinical signs associated with PPIA, largest pituitary gland weights were detected in pregnant and lactating mares, which were most likely associated with increased pars distalis function. ${ }^{5,16,21-23}$ The hypothesis that PPIA in horses may result from a loss of the dopaminergic innervation of the pars intermedia is consistent with the finding that the dopamine concentration of PPIA tissue was $<12 \%$ of that in normal pars intermedia tissue. ${ }^{24}$ Pituitary gland weight was significantly greater in pregnant and lactating mares than nonpregnant mares. Interestingly, nonlactating mares had larger pituitary gland weights than geldings, which is in agreement with results of 1 report $^{13}$ indicating that mean pituitary gland weights in nonpregnant mares was $1.84 \mathrm{~g}\left(\mathrm{n}=373\right.$; RPW $\left.5.5 \times 10^{-6}\right)$, in pregnant mares was $2.06 \mathrm{~g} \mathrm{(6)}$, and in geldings was $1.76 \mathrm{~g}$ (14). Findings of 1 study $^{\mathrm{b}}$ indicate that the largest pituitary gland weights were also detected in mares. An agerelated increase in pituitary gland weight was detected in geldings and mares, but not in any particular reproductive stage in mares. Reportedly, the size and weight of the pituitary gland increase with age in domestic animals in general ${ }^{14}$ which is similar to results of our study. However, results of other studies ${ }^{12, b}$ suggest that weight of pituitary glands decreases with age, although statistical analyses were not performed in both studies. More specific information regarding the effect of age on pituitary cell types was obtained in Mongolian ponies, in which the percentage of somatotrophs decreased with age, regardless of sex, and the percentage of lactotrophs increased with age in stallions. In old mares (15 to 22 years old), the percentage of follicle-stimulating hormone cells increased, whereas the cell area of cells that produce follicle-stimulating hormone and luteinizing hormone decreased. ${ }^{16}$

An age-related increase in the presence of pituitary lesions in the pars distalis and pars intermedia was detected in geldings, mares overall, and nonpregnant mares, but not in pregnant and lactating mares. The fact that the pituitary pars intermedia, but not the pars distalis, contained significantly more lesions in pregnant and lactating mares than geldings and stallions leads to the hypothesis that the pars intermedia in horses may be more sensitive to obvious proliferative 
effects of steroids produced by the ovary than the pars distalis. As a result, the age-related increase in the presence of pituitary lesions in the pars intermedia may have been disturbed because of long-term exposure to steroids produced by the ovary in pregnant and lactating mares. In addition, there is no apparent effect of aging on baseline plasma ACTH concentrations in the horses. ${ }^{25}$ Interestingly, results of 1 study ${ }^{26}$ indicate that tumors of the intermediate lobe of the pituitary gland developed in Syrian hamsters treated with estrogens, whereas long-term administration of estradiol benzoate to ovariectomized rats increased concentrations of serum $\alpha$-melanocyte-stimulating hormone because of enhanced synthetic activity of pars intermedia cells. ${ }^{27}$

In humans, hyperadrenocorticism commonly develops in women of childbearing age, but may develop at any age. ${ }^{28}$ In horses, females are also affected more frequently with PPIA than males. ${ }^{5}$ Results of 8 case series ${ }^{4-9,29,30}$ in horses indicate that PPIA may be more common in females $(n=106)$ than males $(93)$. Furthermore, in the study reported here, there was a predilection for pituitary pars intermedia lesions in pregnant and lactating mares without clinical signs associated with PPIA.

Results of 1 study ${ }^{4}$ indicate that the pituitary gland weight in horses $(n=27)$ ranged from 3 to $12 \mathrm{~g}$. In our study, the maximum pituitary gland weight detected in a horse with PPIA was 13.9 g. Among horses without clinical signs associated with PPIA, $4.4 \%$ of mares had PPIA, similar to results of another study ${ }^{17}$ in which 3\% of mares had PPIA. When ventrodorsal radiography or computed tomography (CT) is being used, preference might be given to the height of the pituitary gland to distinguish normal horses from horses with PPIA because dorsal expansion of the pituitary gland is the only option as a result of the incomplete diaphragma sellae. In the study reported here, height of the pituitary gland was within reference limits in 18\% of mares and $25 \%$ of geldings with PPIA. Results of previous studies ${ }^{5,8}$ indicate that $68 \%$ to $100 \%$ of pituitary glands with macroadenomas of the pars intermedia were enlarged grossly, compared with $82 \%$ and $100 \%$ (on a weight basis) detected in mares and geldings, respectively, in the present study. However, results of 1 study ${ }^{15}$ indicate that pituitary height and volume measurements are less accurate than length and width measurements when determined by use of CT, compared with gross measurements. Computed tomography estimates of length and width of pituitary gland in horses, compared with gross measurements, were more accurate than estimates of height (accuracy, $58 \%$ to $71 \%$ ) or volume. ${ }^{15}$

On the basis of the linear regression equation determined by pituitary gland weight (pituitary gland weight [grams] $=0.02561 \times$ age [years] +2.872$)$, approximately a century would be required for a pituitary gland without PPIA to double its weight in horses without clinical signs associated with PPIA.

No significant association was detected between RPW in horses and ponies with PPIA and plasma ACTH, cortisol, or insulin concentrations or clinical parameters. As a result, the seizures sometimes associated with PPIA obviously resemble vasovagal syncope rather than a space-occupying effect. There was a significant association between RPW and plasma glucose concentration in ponies with PPIA, but not in horses with PPIA, which may be associated with the fact that ponies have lower glucose metabolism ${ }^{31}$ as assessed by means of the euglycemic hyperinsulinemic clamp, rather than an innate insulin resistance, ${ }^{32}$ compared with horses.

${ }^{a}$ Levy M, Blevins WE, Janovitz EB. Radiological diagnosis of pituitary adenoma in the horse (abstr), in Proceedings. 3rd Cong World Equine Vet Assoc 1993;18.

${ }^{b}$ Höser J. Altersveränderungen der Hypophyse des Pferdes. PhD dissertation, Department of Veterinary Pathology, Hannover University, Hannover, Germany, 1941.

'SPSS analytical software, version 7.0, SPSS Inc, Chicago, Ill.

\section{References}

1. Pallaske G. Zur Kasuistik seltener Geschwülste bei den Haustieren. Zeitschr Krebsforsch 1932;36:342-353.

2. Beech J, Garcia M. Diseases of the endocrine system. In: Colahan PT, Mayhew IG, Merritt AM, et al, eds. Equine medicine and surgery. Vol 2. 4th ed. Goleta, Calif: American Veterinary Publications, 1991;1737-1751.

3. van der Kolk JH, Ijzer J, Overgaauw PAM, et al. Pituitary-independent Cushing's syndrome in a horse. Equine Vet J 2001;33:110-112.

4. Lombard LS, Lawrence AM, Phillips TN. Multiple primary endocrine tumors in American horses with Cushing-like disease, in Proceedings. 5th Perugia Quadrennial Intern Conf Cancer 1975;435-450.

5. Heinrichs $M$, Baumgärtner W, Capen CC. Immunocytochemical demonstration of proopiomelanocortinderived peptides in pituitary adenomas of the pars intermedia in horses. Vet Pathol 1990;27:419-425.

6. Boujon CE, Bestetti GE, Meier HP, et al. Equine pituitary adenoma: a functional and morphological study. J Comp Pathol 1993;109:163-178.

7. van der Kolk JH, Kalsbeek HC, van Garderen E, et al. Equine pituitary neoplasia: a clinical report of 21 cases (1990-1992). Vet Rec 1993;133:594-597.

8. Feige K, Wehrli Eser M, Geissbühler U, et al. Klinische Symptomatik und diagnostische Möglichkeiten des Hypophysenadenoms beim Pferd. Schweiz Arch Tierheilkd 2000;142:49-54.

9. Hillyer MH, Taylor FGR, Mair TS, et al. Diagnosis of hyperadrenocorticism in the horse. Equine Vet Educ 1992;4:131-134.

10. Allen JR, Barbee DD, Crisman MV. Diagnosis of equine pituitary tumors by computed tomography-part 1. Compend Contin Educ Pract Vet 1988;10:1103-1106.

11. Tietje S, Becker M, Böckenhoff G. Computed tomographic evaluation of head diseases in the horse: 15 cases. Equine Vet J 1996;28:98-105.

12. Trautmann DR. Die makroskopischen Verhältnisse der Hypophyse einiger Säuger. Arch Wissenschaftl Prakt Tierheilk 1909; 35:617-620.

13. Saito Y. Untersuchungen über die Hypophysengewichte von Pferden. Biochem Zeitschr 1923;142:308-311.

14. Sajonski H. Normale Anatomie und Physiologie der Hypophyse. In: Dobberstein J, Stünzi H, eds. Handbuch der speziellen pathologischen Anatomie der Haustiere. Vol 3. 3rd ed. Berlin: Paul Parey Verlag, 1968;115-134.

15. McKlveen TL, Jones JC, Sponenberg DP, et al. Assessment of the accuracy of computed tomography for measurement of normal equine pituitary glands. Am J Vet Res 2003;64:1387-1394.

16. Tan J-H, Sasaki F. Effect of age on immunocytochemical staining characteristics of adenohypophyseal cells in Mongolian pony mares and stallions. Am J Vet Res 2000;61:826-831.

17. Okada T, Shimomuro T, Oikawa M, et al. Immunocytochemical localization of adrenocorticotropic hormone-immunoreactive cells of the pars intermedia in Thoroughbreds. Am J Vet Res 1997;58:920-924.

18. van der Kolk JH, Wensing T, Kalsbeek HC, et al. Laboratory diagnosis of equine pituitary pars intermedia adenoma. Domest Anim Endocrinol 1995;12:35-39.

19. Wilson MG, Nicholson WE, Holscher MA, et al Proopiolipomelanocortin peptides in normal pituitary, pituitary tumor 
and plasma of normal and Cushing's horses. Endocrinology 1982; 110:941-954.

20. Kulinski KM, Thompson DL Jr, Capshaw EL, et al. Daily treatment of growing foals with equine somatotropin: pathologic and endocrinologic assessments at necropsy and residual effects in live animals. J Anim Sci 2002;80:392-400.

21. Ireland FA, Loch WE, Worthy K, et al. Effects of bromocriptine and perphenazine on prolactin and progesterone concentrations in pregnant pony mares during late gestation. J Reprod Fertil 1991;92:179-186.

22. Worthy K, Escreet R, Renton JP, et al. Plasma prolactin concentrations and cyclic activity in pony mares during parturition and early lactation. J Reprod Fertil 1986;77:569-574.

23. Roser JF, Chang YS, Papkoff H, et al. Development and characterization of a homologous radioimmunoassay for equine prolactin. Proc Soc Exp Biol Med 1984;175:510-517.

24. Millington WR, Dybdal NO, Dawson R Jr, et al. Equine Cushing's disease: differential regulation of $\beta$-endorphin processing in tumours of the intermediate pituitary. Endocrinology 1988;123:1598-1604.

25. McFarlane D, Sellon DC, Gaffney D, et al. Hematologic and serum biochemical variables and plasma corticotropin concentration in healthy aged horses. Am J Vet Res 1998;59:1247-1251.
26. Vasquez-Lopez E. The reaction of the pituitary gland and related hypothalamic centers in the hamster to prolonged treatment with oestrogens. J Pathol Bacteriol 1944;56:1-13.

27. Ferreira AB, Celis ME. Modifications of pars intermedia cells of ovariectomized rats by oestrogen and progesterone. Acta Endocrinol (Copenh) 1986;111:17-24.

28. Thorner MO, Vance ML, Laws ER Jr, et al. The anterior pituitary. In: Wilson JD, Foster DW, Kronenberg HM, et al, eds. Williams textbook of endocrinology. 9th ed. Philadelphia: WB Saunders Co, 1998; 249-340.

29. Couëtil LL, Paradis MR, Knoll J. Plasma adrenocorticotropin concentration in healthy horses and in horses with clinical signs of hyperadrenocorticism. J Vet Intern Med 1996;10:1-6.

30. Schott HC, Coursen CL, Eberhart SW, et al. The Michigan Cushing's project, in Proceedings. 47th Annu Conv Am Assoc Equine Pract 2001;22-24.

31. Rijnen KEPM, van der Kolk JH. Determination of reference range values indicative of glucose metabolism and insulin resistance by use of glucose clamp techniques in horses and ponies. Am J Vet Res 2003;64:1260-1264.

32. Jeffcott LB, Field JR, McLean JG, et al. Glucose tolerance and insulin sensitivity in ponies and Standardbred horses. Equine Vet J 1986;18:97-101.

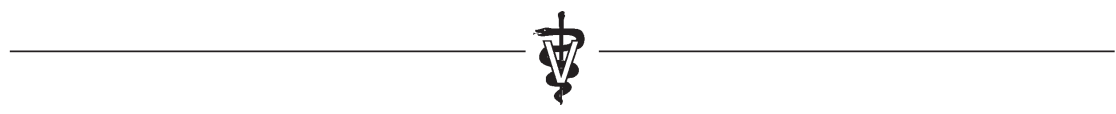

Correction: Evaluation of assays for perinuclear antineutrophilic cytoplasmic antibodies and antibodies to Saccharomyces cerevisiae in dogs with inflammatory bowel disease

In the article "Evaluation of assays for perinuclear antineutrophilic cytoplasmic antibodies and antibodies to Saccharomyces cerevisiae in dogs with inflammatory bowel disease," published September 2004 (2004;65:1279-1283), the table on page 1282 was incorrect. The following table is the corrected version.

Table 1-Results of assays to detect perinuclear antineutrophilic cytoplasmic antibodies (pANCAs) and antibodies to Saccharomyces cerevisiae (ASCAs) via immunofluorescence techniques in healthy control dogs, healthy young working dogs, dogs with acute non-IBD-associated diarrhea, and dogs with chronic non-IBD-associated diarrhea.

\begin{tabular}{|lccc|}
\hline & \multicolumn{2}{c|}{ Test result } & $\begin{array}{c}\text { Specificity } \\
\text { (95\% confidence } \\
\text { interval) }\end{array}$ \\
\cline { 2 - 3 } & Positive & Negative & \\
\hline $\begin{array}{c}\text { pANCA assay } \\
\text { Healthy control } \\
\text { group (n = 26) }\end{array}$ & 3 & 23 & $0.88(0.69-0.97)$ \\
$\begin{array}{c}\text { Healthy working dog } \\
\text { group (22) }\end{array}$ & 4 & 18 & $0.82(0.59-0.94)$ \\
$\begin{array}{c}\text { Acute diarrhea } \\
\text { group (18) } \\
\text { Chronic diarrhea }\end{array}$ & 3 & 15 & $0.83(0.85-0.96)$ \\
$\begin{array}{c}\text { group (19) } \\
\text { ASCA assay } \\
\text { Healthy control } \\
\text { group (26) }\end{array}$ & 1 & 18 & $0.95(0.72-1.00)$ \\
$\begin{array}{c}\text { Healthy working dog } \\
\text { group (22) }\end{array}$ & 6 & 16 & $0.73(0.50-0.88)$ \\
$\begin{array}{c}\text { Acute diarrhea } \\
\text { group (18) }\end{array}$ & 4 & 14 & $0.79(0.54-0.93)$ \\
$\begin{array}{c}\text { Chronic diarrhea } \\
\text { group (19) }\end{array}$ & 8 & 11 & $0.58(0.34-0.79)$ \\
\hline
\end{tabular}

